\title{
Snap-On Cap Plastic Container Closure
}

National Cancer Institute

\section{Source}

National Cancer Institute. Snap-On Cap Plastic Container Closure. NCI Thesaurus. Code C96133.

A non-threaded closure that is pressed onto the package finish with a protruding feature that mates with a similar protruding feature on the closure to secure the closure to the package. 